\title{
МЕТОДИКА ЗАСТОСУВАННЯ СУЧАСНИХ МУЛЬТИМЕДІЙНИХ ТЕХНОЛОГІЙ У ПРОЦЕСІ ФОРМУВАННЯ ПРОФЕСІЙНИХ КОМПЕТЕНТНОСТЕЙ МАЙБУТНІХ ПЕДАГОГІВ
}

vihovomu seredovische: navchalno-methodical vidanny]. Lutsk: Volynskyi natsionalnyi universytet imeni Lesi Ukrainky, 174 p. [in Ukrainian].

4. Romaniuk, L. V. (2004). Tsinnisni oriientatsii studentiv: sutnist, struktura $i$ psykholohichni mekhanizmy rozvytku [Valuable orientations of students: essence, structure and psychological mechanisms of development]. Kamianets-Podilskyi: Abetka, NOVA, 188 p. [in Ukrainian].

5. Zvierieva, I.D. (Ed.). (2008). Sotsialna pedahohika: mala entsyklopediia [Social pedagogy: small encyclopedia]. Kyiv: Tsentr uchbovoi literatury, 336 p. [in Ukrainian].
6. Kharchenko, S. Ya. (2006). Sotsializatsiia ditei ta molodi $v$ protsesi sotsialno-pedahohichnoi diialnosti: Teoriia i praktyka [Monohrafiia]. [Socialization of children and youth in the process of social and pedagogical activity: Theory and practice]. Luhansk: Alma-Mater, 320 p. [in Ukrainian].

7. Shtyfurak, V. Ye. (2007). Sotsialno-pedahohichni osnovy orhanizatsii vykhovnoi roboty $z i$ studentskoiu moloddiu: monohrafiia [Sociopedagogical bases of organization of educational work with student youth]. Vinnytsia: Dilo, 568 p. [in Ukrainian].

Стаття надійшла до редакції 09.03.2018

УДК 378.011.3-051:004

DOI:

Ольга Потапчук, кандидат педагогічних наук, асистент кафедри комп 'ютерних технологій Тернопільського національного педагогічного університету імені Володимира Гнатюка

\section{МЕТОДИКА ЗАСТОСУВАННЯ СУЧАСНИХ МУЛЬТИМЕДІЙНИХ ТЕХНОЛОГІЙ У ПРОЦЕСІ ФОРМУВАННЯ ПРОФЕСІЙНИХ КОМПЕТЕНТНОСТЕЙ МАЙБУТНІХПЕДАГОГІВ}

У статті розкрито актуальність та особливості застосування сучасних мультимедійних технологій 6 навчальному процесі та йх вплив на формування професійних компетентностей майбутніх педагогів. Виділено основні функції мультимедійних технологій в навчальному процесі та запропоновано основні напрямки методичного використання мультимедійних технологій у проиесі формування професійних компетентностей майбутніх педагогічних фахівців. Встановлено, щзо застосування мультимедійних технологій в навчальному прочесі сприяє раиіональній професійній діяльності викладачів, розширюючи його можллвості, крім того, за умови правильного методичного використання дає можсливість економії часу та інтенсифікаиії педагогічного процесу.

Ключові слова: мультимедійні технології, навчальний процес, педагогічні фахівці, інформатизація, професійні компетентності.

Puc. 1. Лim. 5.

Olga Potapchuk, Ph.D.(Pedagogy), assistant of the Computer Technologies Department Ternopil Volodymyr Hnatyuk National Pedagogical University

\section{METHODOLOGY OFAPPLICATIONOFMODERN MULTIMEDIATECHNOLOGIES IS IN THE PROCESS OF FORMING OF PROFESSIONAL COMPETENCE OF FUTURE TEACHERS}

In the article actuality and features of application of modern multimedia technologies in an educational process and their influence are exposed on forming of professional competence of future teachers. The basic functions of multimedia technologies are distinguished in an educational process (recreation of educational information, design, self-education, audiocommunicative, visual) and basic directions of the methodical use of multimedia technologies are offered in the process of forming of professional competence of future pedagogical specialists. Application of multimedia technologies in the process of forming of professional competence of future teacher stakes place for providing of concrete aims: abstracting, explanation and generalizations that are the basic criteria of studies. It is set that application of multimedia technologies in an educational process assists rational professional activity of teachers, extending him to possibility, in addition, on condition of the correct methodical use gives an opportunity to the economy of time and intensification of pedagogical process. However, at the choice of means of multimedia technologies it is necessary to take into account the features of concrete educational discipline, her conformities to law and research methods, and that modern multimedia technologies are effective only in combination with traditional facilities and methods of studies.

Keywords: multimedia technologies, educational process, pedagogical specialists, informatization, are professional competence.

П

остановка проблеми. На сучасному етапі розвитку інноваційних технологій, для успішного соціального розвитку суспільства, система освіти в Україні повинна буги спроможна готувати висококваліфікованих фахівців, які відповідатимуть вимогам інформаційного суспільства та будугь конкуренто-спроможними на сучасному ринку праці. Умови розвитку засобів 


\section{МЕТОДИКА ЗАСТОСУВАННЯ СУЧАСНИХ МУЛЬТИМЕДІЙНИХ ТЕХНОЛОГІЙ У ПРОЦЕСІ ФОРМУВАННЯ ПРОФЕСІЙНИХ КОМПЕТЕНТНОСТЕЙ МАЙБУТНІХ ПЕДАГОГІВ}

навчання сучасної освіти зумовлюються зростаючими інтеграційними процесами, основними складовими яких $€$ новітні інформаційні технології. Щодня освітні технології набувають нових формам та методів навчання, одним із яких $є$ застосування в навчальному процесі сучасних мультимедійних технологій, які відкривають нові можливості у поданні студентам навчальних матеріалів та забезпечують доступність і ефективність отримання необхідної інформації та стають новим освітніми стандартами.

Сучасні технічні засоби сприяють створенню інтерактивного інформаційно-комунікаційного середовища, дають можливості використовувати як традиційні, так і інноваційні педагогічні технології. Застосування таких технологій полягає в розробці нових методичних підходів до організації навчального процесу. Перспективним шляхом удосконалення та оптимізації процесу формування професійних компетентностей майбутніх педагогів є застосування сучасних засобів мультимедійної системи [5].

Новітні мультимедійні технології дозволяють інтенсифікувати навчальний процес, стимулювати розвиток мислення та уяви майбутніх фахівців, формувати дослідницькі, пошукові уміння, здатність самостійно приймати оптимальні рішення, розвивати мотивацію до майбутньої професійної діяльності та навчання в цілому [4].

Однією з ключових дидактичних проблем, що стоять сьогодні перед педагогічною наукою, $є$ не достатньо вирішені завдання створення та застосування в системі вищої освіти технологій навчання, які забезпечили б якісне засвоєння змісту навчання студентами та інтенсивне оволодіння професійними компетентностями.

Аналіз останніх досліджень і публікацій. Науковці та педагоги на сучасному етапі розвитку педагогічної науки докладають чимало зусиль для вирішення зазначеної проблеми. Аналіз праць учених показав, що розробкою елементів інтерактивного навчання, на якій базується теорія і практика розвивального навчання займалися В. Сухомлинський, В. Шаталов, Ш. Амонашвілі, С. Ільїн. Проблемі застосування мультимедійних технологій у навчальному процесі присвячено роботи К. Акуленко, А. Ашеров, І. Бендера, Р. Горбатюк, С. Громов, В. Клочко, О. Потапчук, П. Стефаненко, В. Хоменко та інші.

Складність розв'язання проблеми в системі освіти полягає у суперечності між традиційним розумінням навчального процесу як інтегративної основи навчання студентів та проблемою створення сприятливих умов, із застосуванням сучасних засобів навчання, для іiі успішної реалізації.

Наявність суперечностей між актуальністю проблеми та необхідністю використання сучасних технологій інтерактивного навчання визначили мету статті - розкрити методику застосування сучасних мультимедійних засобів навчання, у процесі формування професійних компетентностей майбутніх педагогів.

Виклад основного матеріалу. В сучасному суспільстві мультимедійні технології знаходять своє застосування в різних галузях, а саме: в мистецтві, освіті, індустрії розваг, техніці, медицині, математиці, бізнесі, наукових дослідженнях, тощо.

Мультимедійні технології в освіті використовують для створення навчальних курсів (E-learning), довідників, енциклопедій та збірників. У зв’язку iз появою мультимедійних технологій, теорія навчання за останні роки була значно розвинена, виділено окремі напрямки досліджень, такі як теорія когнітивного навантаження, мультимедійне навчання та інші [2].

Мультимедійні засоби навчання у системі вищої освіти не можуть виконувати роль педагога, проте їх застосування в навчальному процесі сприятиме удосконаленню діяльності викладача, а в результаті - підвищить ефективність освітнього процесу та якість підготовки майбутніх фахівців. Таку гіпотезу покладено в основу дослідження [1].

Сучасні мультимедійні технології сприяють інтенсифікації навчального процесу, стимулюють розвиток уяви та мислення студентів, дозволяють збільшувати обсяг навчального матеріалу, формувати дослідницькі та аналітичні вміння, схильність приймати самостійне рішення в умовах проблемних ситуацій. Сьогодні умови розвитку засобів навчання в системі вищої освіти зумовлені зростаючими інтеграційними процесами, основними складовими яких є нові інформаційні технології, характерною рисою яких є практично необмежені можливості для самостійної та спільної діяльності викладача та студентів. 3 авторитарного носія інформації викладач виконує роль учасника продуктивної діяльності майбутніх фахівців та створює сприятливе середовище для формування власного інтелекту. Перспективним шляхом удосконалення та оптимізації навчального процесу у ВНЗ є використання мультимедійних технологій, які дають можливість інтенсифікувати навчальний процес, зробити його гнучким, динамічним та посилити його прикладну спрямованість [2].

Поняття “мультимедійні технології” в контексті 


\section{МЕТОДИКА ЗАСТОСУВАННЯ СУЧАСНИХ МУЛЬТИМЕДІЙНИХ ТЕХНОЛОГЙ У ПРОЦЕСІ ФОРМУВАННЯ ПРОФЕСІЙНИХ КОМПЕТЕНТНОСТЕЙ МАЙБУТНІХ ПЕДАГОГІВ}

дослідження розглядаємо, як сучасні комп'ютерні технології, які дозволяють об'єднувати в комп'ютерній системі текст, звук, відео, графічні зображення, анімацію та ефекти віртуальної реальності. Застосування ефекту віртуальної реальності у педагогічному процесі сприяє відчуттю присутності та дає можливість покращити, зробити ефективнішою та якіснішою навчально-виховну систему та в свою чергу сприяє можливості передавати інформацію студентам через їх безпосередній контакт із досліджуваними об'єктами та явищами, моделювати ситуації майбутньої професійної діяльності, у яких майбутнім фахівцям необхідно приймати професійні рішення та діяти відповідно до обставин. Тому, стверджуємо, що дидактичні можливості мультимедійних технологій $€$ невід'ємним компонентом практично будь-якої системи сучасної освіти [1].

У процесі науково-педагогічної діяльності слід використовувати широке поняття "мультимедійні технології”, що включають “мультимедійні засоби”, “мультимедійна інформація”, “мультимедійні продукти”. Мультимедійні засоби поділяються на апаратні (комп'ютер $з$ процесором, мультимедіамонітором із вбудованими стерео-динаміками, TVтюнери, звукові плати, проектори, інтелектуальна дошка (Smart Board), тощо) та програмні (програми та проблемно-орієнтовані мови програмування, що враховують особливості мультимедійних матеріалів). Мультимедійні продукти розглядаємо як документи, що несуть інформацію різних типів і припускають використання спеціальних технічних пристроїв для їх створення та відтворення [4, 34]. Таким чином, побудуємо схему, що наочно відображає ієрархічність понять, що розглядаються.

Сьогодні існує велика кількість програмних засобів для створення мультимедійного контенту. Найбільш популярними $\epsilon$ ті, за допомогою яких можна створювати відеоматеріали навчального призначення та демонструвати прийому роботи. Такими програмними засобами є: Screencast-OMatic, VCASMO, RichMedia, Open Broadcoster Software та ін. Вагомим є те, що усі ці програмні засоби є доступні безкоштовно та мають доступний інтерфейс. Тому, їх застосування можливе не лише для фахівців у галузі комп'ютерних технологій [3].

Характерною рисою сучасних мультимедійних технологій $€$ те, що вони надають можливості самостійної та спільної творчої діяльності викладача та студентів. Роль викладача 3 авторитарного носія інформації змінюється на учасника продуктивної діяльності майбутні фахівців, який створює сприятливе середовище для формування власного інтелекту та професійних компетентностей майбутніх педагогічних фахівців. Сучасні мультимедійні технології навчання базуються на принципах оптимізації, які спрямовані на вдосконалення навчального процесу та якості освіти. Науковопедагогічні фахівці, як суб'єкти навчального процесу, повинні володіти новітніми інформаційними технологіями, які сприяють розв'язку педагогічних задач на відповідному методичному рівні, на основі набутих компетентностей. На сучасному етапі розвитку освіти стають найважливішими такі риси особистості, як творчість, активність, самостійність та здатність адаптуватися до стрімких змін у світі, формування яких вимагає використання сучасних мультимедійних технологій у навчальному процесі на основі реалізації компетентнісного підходу.

Мультимедійні технології в навчальному процесі виконують такі основні функції:

- Відтворення навчальної інформащї, що забезпечує наочність в освітньому процесі та багаторазового використання матеріалів навчальної інформації, яка відображає сутність об'єктів, процесів і явищ, що вивчаються.

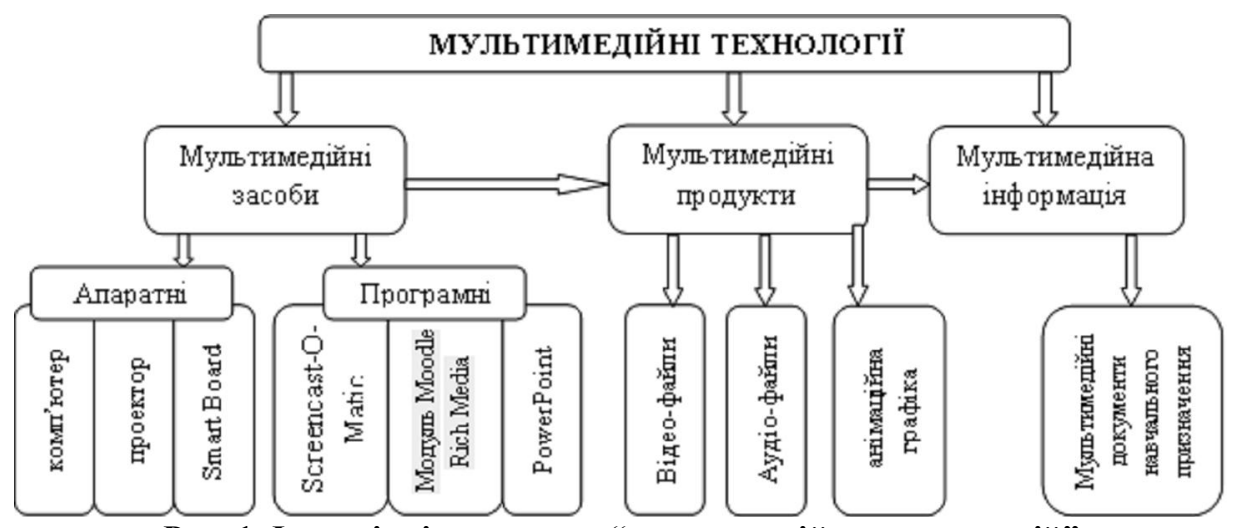

Рис. 1. Ієрархічність понять "мультимедійних технологій" 


\section{МЕТОДИКА ЗАСТОСУВАННЯ СУЧАСНИХ МУЛЬТИМЕДІЙНИХ ТЕХНОЛОГІЙ У ПРОЦЕСІ ФОРМУВАННЯ ПРОФЕСІЙНИХ КОМПЕТЕНТНОСТЕЙ МАЙБУТНІХ ПЕДАГОГІВ}

- Моделювання геометричних, фізичних та математичних схем забезпечують можливість демонструвати і досліджувати динамічні системи і процеси, що вивчаються.

- Самоосвіта. Застосування мультимедійних технологій в навчальному процесі забезпечує сприймання навчальної інформації, контроль і самоконтроль студентами за правильністю їі засвоєння, опосередковане керування пізнавальною діяльністю студентів. Наприклад тренажери, які забезпечують формування потрібних практичних навичок.

- Аудіо-комунікативна. Використання аудіоматеріалів $є$ необхідним і ефективним засобом навчання. Комунікативне навчання характеризується залученням студентів через безпосереднє спілкування і аудіювання.

- Візуальна. Навчальні візуальні матеріали складаються з об'єктів, моделей, діаграм, таблиць, графіків, анімацій, що посилаються на ілюстративні вказівки, слайдів, анімацію. Ефективним засобом навчання є відео-засоби, які відіграють значну роль у мотивації майбутніх фахівців до формування професійної компетентності [2].

Вважаємо, що застосування мультимедійних технологій в процесі формування професійних компетентностей майбутніх педагогів відбувається для забезпечення конкретних цілей: абстрагування, пояснення та узагальнення, які є основними критеріями навчання. Для ефективної та якісної підготовки студентів до майбутньої професійної діяльності, педагог, як суб'єкт навчального процесу, повинен супроводжувати наочний матеріал поясненнями, детальними уточненнями та обговореннями, що сприятиме виведенню належні висновків та освоєнню нового матеріалу майбутніми педагогічними фахівцями.

Використання засобів мультимедійних технологій $\epsilon$ необхідною ланкою у роботі сучасного творчого викладача. Тому, пропонуємо дидактичні напрямки методичного їх використання у процесі формування професійних компетентностей майбугніх педагогічних фахівців:

- розвиток мотивації студентів до навчального процесу;

- урізноманітнення форм подання нового навчального матеріалу;

- забезпечення зворотного зв’язку та можливості діалогізації навчального процесу;

- індивідуалізація процесу навчання, розширення можливостей самоосвіти та самоаналізу;

- широке застосування прийомів освітніх технологій;
- посилення ролі студентів, як суб'єкта навчального процесу, активізація їх освітньої діяльності.

Застосування мультимедійних технологій в процесі формування професійних компетентностей майбутніх педагогічних фахівців на високому методичному рівні сприяє наступному:

- забезпечення мобільності навчального процесу, підвищенню його гнучкості, постійному динамічному вдосконаленні;

- зміні форм і методів організації навчальнопізнавальної діяльності студентів та застосування компетентнісного підходу в навчальному процесі;

- посиленню міждисциплінарних зв'язків та комплексному вивченню явищ і подій;

- мотивації студентів до постійного самовдосконалення та готовності до самоосвіти;

- індивідуалізації навчального процесу 3 урахуванням рівня підготовленості, здібностей, мотивації та потреб студентів;

- характер пізнавальної діяльності студентів набуває пошукового характеру та самостійності.

Отже, на основі проведеного грунтовного аналізу та власного досвіду стверджуємо, що застосування мультимедійних технологій в навчальному процесі сприяє раціональній професійній діяльності викладачів, розширюючи його можливості, крім того, за умови правильного методичного використання дає можливість економії часу та інтенсифікації педагогічного процесу.

Мультимедійні технології, як засіб навчання можна використовувати при проведенні занять різного типу. Наприклад, для мотивації, постановки проблеми та у процесі подання нового навчального матеріалу доцільно застосовувати презентації та короткі відео-уроки, які містять різні види інформації (текстову, звукову, графічну, анімації) та забезпечує ефективному засвоєнню iї студентами. Не менш ефективними є електронні книги та публікації, які є одним із інструментів самостійного навчання майбутніх фахівців. На етапі закріплення та діагностики рівня знань студентів $є$ доцільним використання програм тестового контролю.

Застосування мультимедійних технологій повинно сприяти досягненню цілей і виконанню завдань навчального процесу. Тому, при виборі засобу мультимедійних технологій необхідно враховувати особливості конкретної навчальної дисципліни, іiі закономірностей та методи дослідження. Варто відзначити, що сучасні мультимедійні технології ефективні лише в поєднанні з традиційними засобами і методами навчання, які не слід ігнорувати. 


\section{МЕТОДИКА ЗАСТОСУВАННЯ СУЧАСНИХ МУЛЬТИМЕДІЙНИХ ТЕХНОЛОГІЙ У ПРОЦЕСІ ФОРМУВАННЯ ПРОФЕСІЙНИХ КОМПЕТЕНТНОСТЕЙ МАЙБУТНІХ ПЕДАГОГІВ}

Висновки і перспективи подальших досліджень. Впровадження інформаційнокомунікаційних, зокрема мультимедійних технологій в навчальний процес - важлива дидактична умова формування професійних компетентностей майбутніх педагогічних фахівців на сучасному етапі реформування вищої освіти України й розвитку інформаційного суспільства.

Проте застосування нових засобів навчального процесу має відбуватися з урахуванням певних умов:

- наявність необхідного матеріально-технічного й програмного забезпечення навчального процесу;

- поєднання сучасних засобів мультимедійних технологій і традиційних форм навчання;

- формування у майбутніх педагогічних фахівців необхідної для майбутньої професійної діяльності інформаційної компетентності;

- поєднання продуктивних та репродуктивних методів навчання 3 використанням засобів мультимедійних технологій;

- впровадження у процес професійної підготовки майбутніх педагогів елементів дистанційної форми навчання.

Впровадження мультимедійних технологій у процес професійної підготовки майбутніх педагогів засвідчує утворення нового освітнього простору, названого сучасними науковцями педагогічним інформаційно-комунікаційним середовищем, що відповідає тенденціям інформатизації освіти та вимогам сучасного інформаційного суспільства.

\section{ЛІТЕРАТУРА}

1. Бойко Ю. І. Мультимедіа як інструмент невербального навчання / Ю. І. Бойко [Електронний ресурс]. - Режим доступу: http:// int-konf.org/konf042013/206-boyko-yu-multimedayak-nstrumentneverbalnogo-navchannya-na-zanyattz-nozemnoyi-movi.html.

2. Демехіна I. П. Мультимедійні засоби навчання як вирішальний фактор ефективності навчального процесу / I. П. Демехіна [Електронний ресурс]. - Режим доступу: http:// intkonf.org/demehina-ip-multimediyni-zasobinavchannya-yak-virishalniy-faktor-efektivnostinavchalnogo-protsesu.

3. Міщенко О. А. Види мультимедійних засобів навчання / Педагогічні науки / Стратегічні напрями реформи системи освіти. Харківський національний педагогічний університет імені Г. С. Сковороди / О. А. Міщенко [Електронний peсурс]. - Режим доступу: http:// www.rusnauka.com/25_DN_2008/Pedagogica/ 28714.doc.htm.

4. Петухова Л. Є. Розширення можливостей навчального процесу в умовах інформаційнокомунікаційного педагогічного середовища / Л. Є. Петухова // Збірник наукових праць.Херсон: Видавництво ХДУ, 2010. - № 6. - С. 32-37.

5. Потапчук О. I. Формування готовності майбутніх інженерів-педагогів до професійної діяльності засобами інформаційно-комунікаційних технологій: дис. ... к-та пед. наук: 13.00 .04 / O. I. Потапчук. - Тернопіль, 2016. - 272 с.

\section{REFERENCES}

1. Boiko, Yu. I. (2013). Multymedia yak instrument neverbalnoho navchannia [Multimedia as a nonverbal learning tool]. [Electronic resource]. Access mode: http://int-konf.org/konf042013/206-boyko-yumultimeda-yak-nstrumentneverbalnogo-navchannyanazanyatt-z-nozemnoyi-movi.html. [in Ukrainian].

2. Demekhina, I. P. (2017). Multymediini zasoby navchannia yak vyrishalnyi faktor efektyvnosti navchalnoho protsesu [Multimedia media as a decisive factor in the effectiveness of the learning process]. [Electronic resource]. Access mode: http://intkonf.org/ demehina-ip-multimediyni-zasobi-navchannya-yakvirishalniy-faktor-efektivnosti-navchalnogo-protsesu. [in Ukrainian].

3. Mishchenko, O.A. (2008). Vydy multymediinykh zasobiv navchannia [Types of multimedia learning tools]. Stratehichni napriamy reformy systemy osvity. Kharkivskyi natsionalnyi pedahohichnyi universytet imeni H. S. Skovorody [Electronic resource]. Access mode: http://www.rusnauka.com/25_DN_2008/ Pedagogica/ 28714.doc.html. [in Ukrainian].

4. Petukhova, L. Ye. (2010). Rozshyrennia mozhlyvostei navchalnoho protsesu v umovakh informatsiino-komunikatsiinoho pedahohichnoho seredovyshcha [Expansion of educational process opportunities in the conditions of information and communication pedagogical environment]. Kherson: KhDU Publishing House, no. 6, pp. 32-37. [in Ukrainian].

5. Potapchuk, O. I. (2016). Formuvannia hotovnosti maibutnikh inzheneriv-pedahohiv do profesiinoi diialnosti zasobamy informatsiinokomunikatsiinykh tekhnolohii [Formation of readiness of future engineers-teachers for professional activity by means of information and communication technologies]. Candidate's thesis. 272 p. [in Ukrainian].

Стаття надійшла до редакції 21.02.2018 